\title{
KERUKUNAN HIDUP UMAT BERAGAMA DI DESA MANJUNG KECAMATAN NGAWEN KABUPATEN KLATEN JAWA TENGAH
}

\author{
Oleh : Abd. Kadir M
}

\section{PENDAHULUAN}

Masalah kehidupan beragama di dalam masyarakat kita merupakan masalah yang sangat peka, bahkan merupakan masalah yang paling peka diantara masalah sosial budaya lainnya. Sesuatu masalah sosial akan menjadi ruwet jika masalah tcrsebut menyangkut masalah agama dan kehidupan bcragama.

Dalam kelompok yang dilandasi oleh suatu ajaran agama, keyakinan kcagamaan dari anggoia-anggota kelompok menjadi kuat dan mantap. (Suparlan, 1988:vi) oleh karena ilu agama yang diyakini oleh scscorang anggota kelompok sesuatu agama menjadi atribut dari identitasnya yang mendalam dan mendasar, karena keyakinan agama terscbut mencakup kehormatan dirinya yang tidak dapal dirobah dan diganti begitu saja. Kajian mengenai kerukunan hidup umat beragama sebenarnya adalah kerukunan sebagaimana tcrwujud dalam incraksi antara umat atau penganut agama yang berlainan yang memiliki identitas agama yang mendasar dan mendalam.

Sehubungan dengan hal tersebut di alas yang menjadi pcrmasalahan dalam penelitian kerukunan hidupumat bcragama adalah pengorganisasian identitas dan penggunaannya dalam intcraksi. Oleh karena itu kerukunan hidup umat beragama adalah bagaimana umat beragama itu menyeleksi acuan-acuan dan mengatur identitas dan menggunakannya dalam intcraksi sesuai dengan kontcksnya.

Dengan demikian kerukunan hidup umat bcragama akan dapat tcrwujud apabila simbol-simbol agama yang merupakan atribut dan identitas masing-masing penganut agama tidak diaktifkan dalam mclakukan intcraksi sosial dalam masyarakat. Identitas dan atribut agama itu disimpan dan digunakan dalam interaksi yang bcrhubungan dengan kegiatan masingmasing penganut agama. Timbulnya batas sosial antara umat bcragama adalah konsep antara percaya dengan tidak percaya dan antara bcrimana dengan tidak bcriman. Di lain pihak perbedaan agama tcrsebut diakui adanya, sehinggaumal bcragama bcrsepakat untuk sctuju dalam perbedaan (agree in disergrcement).

Oleh karena itu penelitian kerukunan hidup umat bcragama ini akan mclihat berbagai intcraksi dalam masyarakat dengan mcmusatkan pcrhatian pada pola-pola hubungan intern dan antar umat bcragama dalam struktur kegiatan ekonomi, formal, politik, tctangga, upacara-upacara keagamaan, upacara-upacara sosial, tolong mcnolong, pcrtcmanan/pcrsahabalan dan perkawinan/kekcrabatan. 


\section{METODE KERJA DAN PROSES PENELITIAN}

Penclitian ini dilaksanakan di desa Manjung Kecamatan Ngawen Kabupaten Klaten Jawa Tengah berdasarkan penunjukan Panitia Pelatihan Penclitian Agama (PPA) yang didukung oleh Surat Ijin Penelitian dari Bupati Kcpala Dae rah Tingkat II Klaten. Penclitian ini dilaksanakan dengan menggunakan disiplin Antropologi, dimana agama dilihat sebagai kebudayaan. Dan pcndckatan yang digunakan adalah pendekatan kualitatif, dimana setiap sasaran yang menjadi perhatian dilihat sccara keseluruhan (holistik). Untuk melihat kerukunan hidup umat beragama, tidak hanya melihat hubungan intern dan antar umat beragama dalam kehidupan dan kegiatan kcagamaan, tetapi juga melihat kaitannya dalam kehidupan dan kegiatan ekonomi, formal, politik, tetangga, sosial, tolong menolong, pertemanan dan kekcrabatan. Dalam pcnelitian kualitatif ini pencliti adalah instrumen penclitian, dimana dalam pengumpulan dan analisa data tergantung kepada kemampuan berfikir ilmiah peneliti.

Pelaksanaan penclitian ini bcrlangsung sclama dua bulan, mulai tanggal 1 September sampai tanggal 31 Oktober 1991 dan tinggal di rumah Kepala Dusun di Dukuh Tuban Wetan Manjung. Selama waktu dua bulan tersebut peneliti hanya mengumpulkan data sesuai dengan jadwal kegiatan yang telah disusun dengan menggunakan buku catatan lapangan dan dilengkapi dengan tape recorder dan tustel mini. Selanjutnya data yang dihimpun dalam catatan lapangan atau direkam dalam pita tape recorder didiskripsikan secara lengkap dalam buku-buku deksripsi yang masing-masing buku disiapkan untuk satu jenis data.

Pengumpulan data dan informasi dilakukan dengan tiga cara. Cara yang pertama ialah menyalin dan menfoto copi datadata monografi desa, pcta desa dan seluruh data yang berkaitan dengan penelitian ini. Cara yang kedua ialah melakukan wawancara terbuka dan mendalam terhadap mantan Kepala Desa, perangkat desa, tokohtokoh agama, tokoh-tokoh masyarakat, Komdcs organisasi politik, pengurus lembaga-lcmbaga desa dan bebcrapa orang yang mempunyai stratifikasi ekonomi yang berbeda. Melalui wawancara ini dapatdiketahui Sejarah desa, situasi kehidupan ekonomi, sosial, keagamaan, politik dan gambaran tentang kerukunan intern dan atar umat beragama. Cara yang ketiga ialah melakukan pengamatan tcrlibat dalam berbagai kegiatan yang dilakukan oleh masyarakat, sepcrti upacara-upacara keagamaan, upacara-upacara sosial, kegiatan ekonomi dan pertemuan-pertcmuan yang dilakukan oleh setiap kelompok dalam masyarakat. Melalui pengamatan ini dapat diketahui keterlibatan kelompok dan pengorganisasiannya dalam kegiatan tersebut serta identitas yang ditonjolkan yang dapat mengarah kepada terciptanya kerukunan atau ketidak rukunan intern atau antar umat beragama.

Data yang dikumpulkan di dalam buku deskripsi dikategorisasi dan dianlisasi kemudian disusun menjadi laporan hasil penelitian tentang kerukunan hidup umat beragama di desa Manjung. 


\section{GAMBARAN UMUM LOKASI PENELITIAN}

Desa Manjung adalah salah satu dari tiga belas desa yang tcrdapat dalam wilayah Kecamatan Ngawen Kabupaten Klaten Jawa Tengah. Jarak desa ini dari pusat ibukota Kabupaten $4 \mathrm{Km}$. dan dari ibukota kecama$\tan 3,5 \mathrm{~km}$. Dan secara geografis desa ini bcrbatasan dengan wilayah kota administratif Klaten di scbclahselatan, sebclah timur bcrbatasan dengan desa Senden, sebclah utara bcrbatasan dengan desa Gatak dan sebelahbarat bcrbatasan dengan desa Duwct Kecamatan Ngawen. Walaupun desa ini berbatasan dengan wilayah kota, namun jalur angkutan bis kota belum lersedia, sehingga untuk mcncapai desa ini menggunakan angkutan beca, dokar dan ojek sepeda motor dengan biaya Rp.2000. Akibat biaya transport ini termasuk mahal, kebanyakan penduduk menggunakan sepeda, disamping sepeda motor dan mobil yang jumlahnya scdikit.

Luas wilayah Desa Manjung 131.6585 ha. Wilayah ini memiliki sumbcrdaya alam yang dapat momenuhi kebutuhan kesejahteraan p73hidupmasyarakat. Lahan persawahan yang seluruhnya mempergunakan irigasi seluas 83.1255 ha. (63\% dari luas wilayah desa), sedangkan sisanya 3.1205 ha. terdiri dari sungai, jalan dan kuburan.

Pola pemukiman penduduk di Manjung adalah pola mengclompok dan padat di bagian timur dan utara wilayah desa, antara satu dukuh dengan dukuh yang lainnya saling bersambungan yang dihubungkan olch jalan-jalan yang sudah dibeton. Antara wilayah pemukiman dan persawahan di- batasi oleh jalan desa yang memanjang dari arah tenggara ke barat laut.

Secara administratif wilayah desa Manjung terdiri dari 2 dusun, 9 dukuh, 10 Rw dan 32 Rt. Dalam melaksanakan tugas pcngelolaan administrasi desa Kcpala Desa dibantu oleh sekretaris desa yang terdiri dari sckretaris dan kepala-kcpala urusan, sedangkan dua kcpala dusun mcmbantu kcpala desa dalam ketcrtiban dan kcamanan.

Penduduk desa Manjung menurut data bulan Agustus 1991 bcrjumlah 3258 jiwa, terdiri dari 1592 jiwa laki-laki dan 1666 jiwa wanita. Dengan jumlah rumah tangga 549 KK bcrarli setiap rumah tangga penduduk berpenghuni rata-rata 6 orang. Dengan luas wilayah 131.6585 ha. bcrarti kepadatan penduduk rata-rata 2474 orang setiap kilo meter pcrsegi.

Klassifikasi penduduk dari segi pendidikan ialah : tidak sekolah 155 orang, belum tamat SD 523 orang, tidak tamat SD 420 orang, tamat SD/sedcrajat 1405 orang, tamat SLTP 241 orang, tamat SLTA 143 orang dan tamat pcrguruan tinggi/akademi 31 orang. Dari data tcrscbut menunjukkan bahwa pcrhatian masyarakat terhadap pendidikan cukup tinggi.

Kalassifikasi penduduk menurut agama ialah Islam 2130 orang $(65,4 \%)$, penganut agama Hindu 610 orang $(18,7 \%)$, penganut agama Katolik 338 orang $(10,4 \%)$ dan penganut agama Kristen Protestan 180 orang (5.5\%) masing-masing kelompok agama tcrscbut memiliki organisasi agama yang membina ummatnya dalam melakukan kegiatan dan aktifitas keagamaan.

Melihat komposisi usia penduduk menunjukkan bahwa penduduk yang berusia 0 sampai 14 tahun 1254 orang (38\%), 
sedangkan yang berusia 55 tahun ke atas berjumlah 309 orang (9\%). Hal ini penduduk yang berusia produktif lebih banyak dari pada usia yang kurang produktif.

Penduduk yang berusia produktif menekuni bidang-bidang kegiatan yang yang menjadi sumber mata pencaharian yang berbagai macam, yaitu petani pemilik, buruh, tani, pengusaha, buruh industri, buruh bangunan, pedagang, pengangkutan dan pegawai negeri baik sipil raaupun ABRI. $B$ agian terbesar penduduk menekuni bidang industri,kemudian pertanian dan perdagangan.

\section{POLA-POLA HUBUNGAN UMAT BERAGAMA}

Kerukunan hidup umat beragama yang menjadi fokus penelitian ini adalah kerukunan hidup intern umat Islam dan kerukunan hidup antara empat kelompok umat beragama yang ada di desa Manjung yaitu Islam, Hindu, Katolik dan Kristen Protestan. Untuk melihat wujud kerukunan intern dan antarumat beragama dapat dilihat pada pola-pola hubungan inter dan antar umat beragama dalam struktur kegiatan ekonomi, formal, politik, tetangga, upacara-upacara keagamaan, upacara-upacara sosial, tolong mcnolong, pertemanan dan perkawinan.

Dalam kegiatan ekonomi umat beragama di desa manjung bckerja dalam berbagai mata pencaharian untuk memenuhi kebutuhan hidupnya sehati-hari dan keluarganya. Sctiap ummat beragama tidak memonopoli suatu mata pencaharian tertcntu, tetapi umat beragama itu bekerja pada setiap macam mata pencaharian. Un- tuk memenuhi kebutuhan hidup di bidang ekonomi umat beragama saling bekerja sama, seperti dalam kegiatan pertanian, industri dan perdagangan.

Penduduk desa Manjung yang bekerja di bidang pertanian adalah 357 orang $(32,9 \%)$, terdiri dari petani sendiri 144 orang dan buruh tani 213 orang. Petani sendiri adalah petani yang mengerjakan sawahnya sendiri, sedangkan buruh tani adalah petani yang tidak memiliki sawah, tetapi menggarap sawah orang lain dengan sistim bagi hasil atau gaji harian.

Antara pemilik sawah, petani sendiri dan buruh tani selalu terjadi hubungan. Hubungan terscbut adalah hubungan kerja yang saling membutuhkan, tanpa disadari oleh latar belakang kelompok atau golongan agama. Pemilik sawah dan petani sendiri yang beragama Islam mempekerjakan buruh tani yang beragama lain, seperti buruh tani Kristen, Katolik dan Hindu, demikian pula sebaliknya. Sistim bagi hasil dan upah harian yang berlaku berdasarkan ketentuan urn urn yang berlaku dalam masyarakat, tanpa adanya perbedaan, karena latar belakang kelompok maupun agama.

Demikian pula di bidang industri terjadi hubungan kerja antara pengusaha dengan buruh. Jumlah penduduk yang bekerja di bidang industri 504 orang $(46,4 \%)$, terdiri dari pengusaha 60 orang dan buruh 444 orang. Industri yang ada di desa Manjung adalah idustri soun, genteng, batu merah dan penggilingan padi. Dalam hubungan kerja di bidang industri ini tidak ada pengaruh golongan dan agama, sedangkan penggajian buruh di dasarkan pada volume, frckwensi dan prestasi kerja. 
Dalam kegiatan perdagangan juga melibatkan kelompok dan golongan agama. Pedagang yang menganut suatu agama mempekerjakan tenaga kerja berdasarkan kemampuan dan prestasi kerj a mereka, tanpa dipengaruhi oleh latar belakang kelompok dan golongan agama.

Usaha untuk meningkatkan kesejahteraan ekonomi masyarakat di Manjung telah terbentuk beberapa kelompok arisan dan simpanpinj am, yaitu: Usaha bersama Arisan Manjung, Simpan pinjam Sedyo Rukun Tuban Kulon dan Arisan Manunggal Cipto. Pengurus dan anggota kelompok simpan pinjam dan arisan ini terdiri dari bermacam-macam agama, dimana setiap minggu atau setiap bulan melaksanakan pertemuan dan kegiatan, sehingga ummat beragama selalu bertemu dan bekerjasama tanpa menonjolkan identitas agama dan kelompoknya masingmasing.

Selanjutnya tingkatan ekonomi dapat diklassifikasi kepda tiga golongan, yaitu golongan ekonomi tinggi, sedang dan rendah. Masing-masing tingkat ekonomi itu tidak hanya dimonopoli oleh satu kelompok agama tertentu, tetapi masing-masing penganut agama menempati kctiga jenjang tingkat ekonomi tersebut, sehingga antara penganut sesuatu agama tidak mempunyai ketergantungankepadapenganutagamalain.

\section{Formal}

Hubungan intern dan antar umat beragama dapat terjalin dalam hubungan formal dan informal. Diantara hubungan formal adalah hubungan dalam lembagalembaga formal yang ada di desa, seperti pemerintahan desa dan Lembaga Ketahanan
Masyarakat Desa (KMD).

Seluruh perangkat desa Manjung beragama Islam, tetapi ada yang tergolong aktif melaksanakan ibadah dan ada yang tidak aktif. p73 Kendatipun demikian hubungan inter dan antar umat beragama terjalin dengan baik, sehingga program dan peraturan pemerintahan desa dipatuhi oleh masyarakat tanpa didasari oleh faklor agama, demikian pula sebaliknya kebu tahankebutuhan masyarakat yang menyangkut urusan pemerintahan desa dilayani dengan baik oleh seluruh perangkat desa tanpa mempcrhatikan latar belakang agama dan golongan.

Untuk membantu pemerintah dalam pelaksanaan pembangunan di desa, maka peranan LKMD sangat penting. Dalam rangka menciptakan kerukunan dan kekompakan masyarakat, maka pengurus dan anggota LKMD Desa Manjung terdiri dari bermacam-macam golongan dan agama. Dari jumlah47 orang pengurus dan anggota LKMD, 25 orang beragama Islam- (53\%), beragama Katolik 10 orang (21\%), beragama Kristen Protcstan 6 orang (13\%) dan beragama Hindu 6 orang (13\%). Oleh karcna itu segala kegiatan yang diusulkan dan dilaksanakan oleh LKMD, merupakan program seluruh umat beragama, yang disetujui dan direstui oleh pemerintah desa.

Hubungan masyarakat yang berbedabeda agama dengan pemimpin formal tctap rukun, sehingga seluruh kegiatan yang dilaksanakan oleh kelompok agama selalu disampaikan kepada pemerintah desa untuk mendapatpersetujuannya. Dan setiap kegiatan yang dilaksanakan oleh masyarakat selalu dilibatkan perangkat desa sebagai 
pemimpin formal di desa.

\section{Politik}

Politik yang dimaksudkan disini ialah : Interaksi individu-individu dengan lembaga-lcmbaga yang menyusun dan melaksanakan cara dan sarana untuk memcrintah suatu masyarakat yang terorganisasikan ("Widjaja, 1986:29). Politik ini terwujud melalui organisasi-organisasi politik. Ada tiga organisasi politik yang ada di desa Manjung ialah Partai Persatuan Pembangunan (PPP), Golongan Karya (Golkar) dan Partai Demokrasi Indonesia (PDI). Dalam menghadapi pemilihan umum tahun 1992, maka telah terbentuk komisariat Desa (Komdes) bagi ketiga orpol untuk menggalang massa dan memperolch pendukung dan simpatisan sebanyak-sebanyak, agar dalam pemilu dapat memperoleh suara terbanyak.

Dalam kaitannya dengan politik hubungan antar ummat beragama akan terjalin pada dua organisasi politik yang dapat menghimpunseluruh penganut agama dalam menyalurkan aspirasi politiknya, yaitu Golkar dan PDI. Ketua organisasi politik ini merupakan organisasi politik yang banyak melaksanakan kegiatan dalam masyarakat. Kedua organisasi ini tidaklah didominasi oleh salah satu penganut agama, letapi seluruh penganut agama yang berbeda-beda itu diberi kesempatan untuk menyalurkan aspirasi politiknya tanpa adanya perbedaan, schingga hubungan antar umat beragama di bidang politik terjalin dengan baik.

Umat Islam di desaManjung, disamping menyalurkan aspirasi politiknya pada Golkar dan PDI, juga menyalurkan pada PPP,

kendatipun yang menyalurkan aspirasinya ke PPP itu sebahagian kecil Islam yang aktif melaksanakan ibadah, sehingga PPP di desa Manjung selalu diidentikkan dengan Partai Islam. Oleh karena itu kegiatan PPP tidak nampak karena pendukung dan simpatisannya sedikit.

Dengan demikian antara satu pemeluk agama dengan agama lain tidak ada saling ketergantungan di bidang politik, sehingga masing-masing pemeluk agama bebas menyalurkan aspirasi politiknya. Kendatipun ada ketergantungan, tetapi ketergantungan itu bukan masalah agama. Ketergantungan itu adalah karena profesi atau jabatan.

\section{Tetangga}

Dalam hubunganketetanggaan intern dan antar umat bcragama selalu dij aga agar tetap terjalin dengan baik. Hal tersebut merupakan pencerminan budaya Jawa. Suatu rumah tangga di Jawa terutama harus berusaha menjalin suatu hubungan yang baik dengan para tctangganya (tetanggi), kemudian keluarga-keluarga lain sekampung, lalu keluarga-keluarga lain se dukuh, dan baru kemudian dengan keluarga-keluarga yang tinggal di dukuh-dukuh lain. (Koentjaramrrat, 1984:151). Hubungan baik dengan r.etangga-tetangga tcrsebut mereka menyatakan dengan berbagai tolong menolong dan gotong royong, tanpa memperhatikan identitas agamanya masing-masing.

Apabila seorang tetangga yang menganut suatu agama melaksanakan kegiatan dan acara, maka para tetangga datang membantunya, baik bantuan tenaga maupun bantuan materi, dengan tidak memperhatikan latar belakang agamanya, Jika upa- 
cara selamatan dilaksanakan, maka anggota group kenduri yang berlain-lainan agama itu datang hadir dan berdoa sesuai dengan keyakinan agamanya, kendatipun yang memimpindoa itu adalah tokoh agama sesuai dengan agama orang yang melaksanakan selamatan.

Setiap ada kegiatan dan acara di dalam masyarakat, selalu diadakan lek-lekan pada malam hari, Para tetangga datang menghadirinya, sambil disuguhi makanan dan minuman oleh tuan rumah yang melaksanakan acara. Pada acara ini berbaur antara penganut agama yang berlainan, mereka bertemu dan berbincang-bincang dengan akrab sebagai tetangga. Biasanya pada setiap lek-lekan dilaksanakan permainan kartu domino atau remis, sehingga orang-orang yang gemar bermain kartu membuat kelompok, tanpa membedakan agama masing-masing. Permainan kartu ini membuat suasana lek-lekan menjadi ramai, walaupun sebagian penganut agama itu menyalah gunakan lek-lekan itu sebagai arena taruhan uang.

Apabila ada tetangga yang ditimpa musibah, sakit atau kematian, maka tetangga itu segera datang membesuk dan membantu tanpa membedakan agama. Jika orang sakit membutuhkan pertolongan ke rumah sakit, tetangga itu segera mengusahakan untuk dibawa ke rumah sakit. Kalau seseorang tetangga meninggal dunia, maka dengan segera para tetangga membantu mempersiapkan segala sesuatu yang berhubungan dengan pelaksanaan pemakaman.

\section{Upacara-upacara keagamaan}

Dalam pelaksanaan upacara-upacara keagamaan intern umat beragama be- kerjasama dengan penuh kerukunan tanpa membedakan kelompok, sedangkan upacara-upacara keagamaan antar umat beragama mempunyai batas sosial karena perbedaan perinsip ajaran agama masingmasing. Namun demikian antara penganut agama dengan yang lainnya tetap saling menghormati dengan penuh pengertian.

Pelaksanaan upacara-upacara keagamaan bagi umat Islam dan Hindu kebanyakan dipusatkan di rum ah-rum ah ibadah yang ada, sedangkan umat Kristen Protestan dan Katolik, masih dilaksanakan di rumah-rumah warganya, karena belum memiliki rumah ibadah. Kendatipun demikian pelaksanaan kebaktian atau misa di rumah warga yang beragama Katolik dan beragama Kristen Protestan, tidak pernah mendapat gangguan dari tetangganya yang beragama lain, karena mereka sudah mengerti bahwa ibadah atau sembahyangan yang dilaksanakan oleh suatu agama merupakan ketaatan penganutnya terhadap agamanya. Pelaksanaan kebaktian di rumah warga Kristen Protestan yang dijadikan sebagai tempat ibadah pada setiap hari Minggu pagi, dianggap ummat yang beragama lain sebagai hal yang wajar saja, karena pelaksanaan ibadah itu adalah hak warga penganut suatu agama.

Upacara-upacara keagamaan yang bersifat sosial, dilaksanakan dengan penuh toleransi, seperti saling mengunjungi pada hari raya idul fitri, tanpa membedakan latar belakang agama. Pada hari natal umat Katolik dan Kristen mengirimkan dan memberikan makanan kepada tetangga yang beragama lain.

Acara tahlilan dan sembahyangan pada upacara selamatan kematian, dilaksanakan 
oleh masing-masing kclompok agama, sedangkan kehadiran kelompok agama lain tidak ikut dalam acara tersebut, melainkan duduk di kelompok lain menanti sclesainya acara tersebut. Setelah acara selesai, mereka bersama-sama dengan berbagai macam agama yang hadir untuk menikmati makanan dan minuman yang dihidangkan.

\section{Upacara-upacara sosial}

Pelaksanaan upacara-upacara sosial di desa Manjung selalu mclibatkan intern dan antar umat bcragama. Dalam upacara ini antar Islam yang aktif dengan Islam yang tidak aktif, antara golongan Muhammadiyah dengan non Muhammadiyah saling bertcmu tanpa menonjolkan identitas kelompoknya, dcmikian pula antara penganut agama yang berbcda terjadi intcraksi tanpa menonjolkan identitas agama. Upacaraupacara sosial tersebut adalah upacara yang bcrhubungan dengan lingkaran hidup, upacara yang berdasarkanwaktu-waktutertcntu dan upacara yang bcrkaitan dengan peringatan hari besar nasional.

Upacara yang bcrhubungan dengan lingkaran hidup ialah upacara mitoni, upacara brokohan, sebasaran, selapangan, upacara tetesan dan supitan, upacara perkawinan, upacara kematian sur tanah, tiga hari, tujuh hari, empat puluh hari, seratus hari, satu tahun dua tahun dan scribu hari. Dalam upacara lingkaran hidup ini, tetangga, group kenduri dan kenalan diundang untuk ikut serta dalam upaara tersebut tanpa melihallatarbelakang agama, sedangkan orangorang yang diundang datang mcmberikan bantuan dan sumbangan, sehingga terjalin dengan baik antara ummat bcragama,
Mereka datang dan bertemu tanpa menonjolkan identitas agamanya.

Upacara sosial yang berhubungan dengan waktu-waktu tertentu ialah upacara sadranan yang dilaksanakan pada bulan Ruwah, sedangkan tempat pelaksanaannya adalah di masing-masing kuburan yang ada dalam desa. Pemimpin upacara ini ditunjuk salah seorang tokoh agama yang disepakati bersama oleh peserta upacara. Kebanyakan pemimpin upacara ini adalah tokoh Islam, karena mayoritas yang hadir adalah orangorang Islam. Doa yang dibaca dalam upacara sadranan ini adakalanya doa yang mempergunakan bahasa Arab atau doa yang bcrbahasa Jawa. Pembacaan doa itu tidaklah menjadi pcrmasalahan umat yang beragama, karena prinsipnya bahwa doa itu ditujukan kepada Gusti untuk keselamatan.

Upacara sosial dalam rangka memperingati hari besar nasional ialah selamatan tujuh belasan (17 Agustus) yang dilaksanakan pada malam tanggal tujuh belas Agustus. Sedangkan yang memimpin doa berdasarkan kesepakatan bersama dalam kelompok selamatan tersebut. Pelaksanaan upacara ini di desa Manjung berfariasi, ada yang melaksanakan pada tingkat RW dan ada yang melaksanakannya pada tingkat RT. Doa yang dibaca juga berdasarkan kesepakatan kelompok, apakah doa itu sesuai dengan doa Islam atau doa dengan menggunakan bahasa Jawa. Hal tersebut dilaksanakan untuk menjadi konflik antara umat beragama.

\section{Tolong menolong}

Salah satu sifat yang masih membudaya dalam masy arakat Manj ung ial ah si fat tolong 
menolong, terutama tolong menolong antara tetangga. Jika seorang tetangga yang melaksanakan kegiatan, maka tetangga yang lainnya datang membantunya, apakah bantiiannya berupa tenaga atau berupa uang yang diberikan kepada tetangga yang melakukan kegiatan.

Dalam rangka tolong menolong ini, pada setiap RW dibentuk perkumpulan muda mudi yang menghimpun seluruh remaja dengan berbagai macam agama, sehingga bila ada salah seorang warga RW yang melaksanakan hajatanatauditimpamusibah, maka anggota perkumpulan muda mudi tersebut bekerjasama dan tolong menolong mcmbantu pelaksanaan kegiatan tersebut sampai selesai.

Disamping tolong menolong dalam bentuk tenaga dan mated, juga tolong menolong dalam bentuk pinjam mcminjam, seperti pinjam meminjam uang dalam acara kematian dan acara perkawinan scrta pinjam mcminjam peralatan yang dibuluhkan.

\section{Pertemuan/persahabatan}

Hubungan intern dan antar umat beragama dalam pertemanan dan persahabatan terjalin dengan baik, apakah pertemanan itu didasarkankarcna profesi, sckelompok atau seperjuangan. Hubungan pertemanan itu tidak menjadi kendala karena perbedaan agama, karena identitas agama masingmasing disimpan dan tidak dinampakkan.

Hubungan pertemanan itu dilaksanakan pada hari raya, untuk saling mcmaalkan atau salingmengucapkan selamat, demikian pula saling tolong menolong atau saling memberikan hadiah dan kenang-kenangan, untuk lebih mempererat hubungan tersebut.

\section{Perkawinan/kekerabatan.}

Perkawinan mcrupakan dambaan setiap remaja yang menanjak dewasa. Dan di desa Manjung untuk mencari jodoh itu, orang tua hanya menyerahkan kepada anaknya, sedangkan orang tua hanya merestui dan melaksanakan acara perkawinan itu. Khusus umat Islam tetap menginginkan agar anakanaknya dapat kawin dan mendapatkan jodoh sesuai dengan agama yang dianutnya, namun diantara anak-anak orang Islam ada yang terlanjur memilih jodoh dengan agama lain, sehingga harus salah satu dari kedua orang tersebut mengikuti agama yang lain. Oleh karena salah satu dari yang berlainan agama itu harus pindah agama, sehingga di desa Manjung jarang terjadi perkawinan antar agama. Salah satu kasus di dukuh Tuban Kulon, seorang wanita yang beragama Katolik, bapaknya beragama Hindu, sedangkan calon suaminya adalah orang Islam. Pelaksanaan perkawinan dilaksanakan secara Islam, dengan akad nikah yang dipimpin oleh naig, karena wanita tersebut masuk Islam, sedangkan bapaknya mengaku juga beragama Islam dengan mengucapkan syahadat di depan naib. Kejadian semacam ini dianggap suatu hal yang wajar oleh masyarakat Manjung, karena anggapan mcreka agama itu adalah mcrupakan perinsip pribadi individu yang bcrsangkutan.

Akibat perkawinan tersebut, menyebabkan adanya beberapa kcluarga di desa Manjung terdiri dari bermacam-macam agama, seperti bapak dan ibu beragama Hindu, sedangkan anak-anaknya ada yang beragama Islam, Kristen atau Katolik, dan demikian pula scbaliknya. 


\section{KESIMPULAN DAN SARAN}

Pola-pola hubungan interndan antar umat bcragama dalam struktur kegiatan-kcgiatan yang telah discbutkan, menunjukkan bahwa kerukunan hidup umat bcragama di desa Manjung berjalan dengan baik, baik intern ummat Islam, maupun antar umat beragama. Wujud Kerukunan itu nampak, karena masing-masing penganut agama tidak mengaktifkan identitas agamanya di dalam melakukan interaksi, sehingga batasbatas sosial yang didasarkan atas perbedaan agama tidak nampak.

Umat bcragama di desa Manjung dalam melakukan aktifitas yang bcrkaitan sosial kemasyarkatan, walaupun mcreka berbeda agama, simbol-simbol agama tidak pemah ditonjolkan dan identitas agama tidak diaklifkan, sehingga hal tcrsebut mcngkondisikan terwujudnya kerukunan, tcrutama dalam hubungan ekonomi, kctetanggaan, kckerabatan, pcrtemanan. tolong mcnolong, upacara sosial dan perkawinan. Batas-batas sosial antar umat beragama akan nampak pada kegiatan upacara-upacara kcagamaan yang bcrsifat ritual, karena dalam kegiatan ini identitas dan simbol agama diaktifkan.

Faktor-faklor yang mendukung terwujudnya kerukunan umat bcragamadi desa Manjung ialah perasaan mcmiliki satu kebudayaan yang sama, yaitu kebudayaan Jawa yang menjadi pedoman bertindak dan bcrkclakuan. Hal ini sesuai dengan pendapat Hildrcd Gecrtz bahwa ada dua kaidah yang paling menentukan pola pergaulan dalam masyarakat Jawa, Kaidah pertama mengatakan, bahwa dalam setiap siluasi manusia hendaknya bersikap sedemikian rupa hingga tidak sampai menimbulkan konflik. Kaidah kedua menuntut agar manusia dalam cara bicara dan membawa diri selalu menunjukkan sikap hormat terhadap orang lain, sesuai dengan derajat kedudukannya (Suscno, 1988:38).

Disamping itu faktor yang mendukung kerukunan adalah pola kepemimpinan formal dan informal di desa Manjung. Pola kepemimpinan formal desa terbuka dan netral lerhadap seluruh penganut agama yang berbeda, scdangkan pola kepemimpinan informal, sepcrti pemimpin agama tidak mengkondisikan konflik, karena meskipun mereka berbeda agama, mcreka menghargai dan mcngakui perbedaan itu.

Faktor pendukung lainnya adalah tingginya perasaan gorong royong dan kerjasama diantara warga masyarakat. Hal inidilunjang oleh wilayahpemukiman yang tidak mengclompok antara satu penganut agama, tctapi mcreka saling bertetangga penganut agama yang berbeda.

Bcrdasarkan dengan kcsimpulan di atas saran yang dapat disampaikan dalam kaitan dengan kerukunan hidup umat beragama adalah scbagai berikut: Pertama perlunya dilcstarikan kebudayaan lokal yang mendukung terciptanya kerukunan umat beragama dan diangkat sebagai kebudayaan nasional. Kedua perlunya budaya gorong royong dan kerjasama dilestarikan di dalam kehidupan bcrbangsa dan bernegara, demi terciptanya stabilitas nasional yang mantap. Kctiga perlunya bimbingan dan pembinaan kcagamaan yang lebih intensif terhadap ummat beragama yang masihmengganggap agama itu sebagai ageman (pakaian) yang dapat diganti sesuai dengan kondisi dan situasi. 


\section{DAFTAR BACAAN}

Barth, Fredrik Kelompok-kelompok Etnik dan Batasannya, Jakarta, Penerbit Universitas Indonesia, 1988

Geertz, Clifford Abangan, Santri, Priyayi Dalam Masyarakat Jawa, Jakarta, Pustaka Jaya. 1989

Koentjaraningrat Kebudayaan Jawa, Jakarta, PN.Balai Pustaka. 1984

1985 Manusia dan Kebudayaan di Indonesia, Jakarta, Penerbit Djambatan
Magnis Suseno, Frans Etika Jawa Sebuah Analisa Falsafi Tentang Kebijaksanaan Hidup Jawa, Jakarta, FT. Gramedia. 1988

Nasikun Sistem Sosial Indonesia, Jakarta, Rajawali 1991

Suparlan, Parsudi dalam Robertson, Roland (cd.)

1988 Agama Dalam Analisa dan Interpretasi Sosiologis, Jakarta, Rajawali

Saifuddin, Akhmad Fedyani Kbnflik dan Intergrasi, Perbcdaan Faham Dalam Agama Islam, Jakarta, Rajawali 1982 